\title{
Christmas Island
}

National Cancer Institute

\section{Source}

National Cancer Institute. Christmas Island. NCI Thesaurus. Code C44482.

An Australian-administered island in the eastern Indian Ocean south of Java, Indonesia. 